\title{
Prospects of Rice Husk Gasification for Power Generation in Bangladesh
}

\author{
Barun Kumar Das`, Nirendra Nath Mustafi and S.M. Najmul Hoque
}

\begin{abstract}
Department of Mechanical Engineering, Rajshahi University of Engineering \& Technology (RUET), Rajshahi6204, Bangladesh
\end{abstract}

\begin{abstract}
Electricity is the basic requirement to promote socio-economic development. In recent years, Bangladesh is facing severe power crisis all over the country, but the rural areas are the most vulnerable. This acute electricity crisis along with the conventional fuel crunch is affecting every sector of the country and economy is being crippled. To reduce the dependency on fossil fuels, rice husk which are widely abundant agricultural waste from rice industry could play a vital role in this regards. Bangladesh is an agricultural country and produces huge quantity of rice every year. In the year 2011, the total rice production was around 50.63 million tones. Husk is the waste biomass produce during the rice processing, on average it accounts around $20 \%$ of the rice produced on weight basis (10.12 million tones). The potential of power generation from rice husk by gasification is around $310 \mathrm{MWe}$ in Bangladesh. The power plant to be installed near the large rice mills 'cluster areas' in Dinajpur, Bogra, Naogaon, Chapainawabganj and Ishwardi with the surplus rice husk. This paper consolidates information from various studies on the availability of rice husk, its characterization and estimates possible power potential that can be realized.
\end{abstract}

Keywords: Rice husk, biomass, gasification, producer gas, rural electrification.

\section{INTRODUCTION}

The present electricity access to people is approximately $49 \%$ in Bangladesh. The major part of this electricity is delivered from natural gas. The reserve of this natural gas however is currently under threat and government is therefore becoming desperate to think of alternatives of natural gas. In the recent years the government is allowing to produce electricity from heavy fuel oil (i.e. furnace oil) which is imported at a high rate. The installed capacity in Bangladesh is increased by roughly $3,415 \mathrm{MW}$ between 2009 and 2012 and is now about 8,535MW [1]. According to reports, Bangladesh at present generates $5000 \mathrm{MW}$ power. Peak hour demand is $6,000 \mathrm{MW}$ everyday and increases on hot summer days. More than $67.21 \%$ of the power plants are fired by gas. Hydro power is responsible only for $2.58 \%$ of the total electricity supply. HFO based power plants share around $22.37 \%$ of total electricity. The acute gas shortage causes a loss in production of around 600MW [1]. Electricity generation scenario by fuel type is presented in Table 1. Due to the shortage of fossil fuel, government has focused on the renewable energy technology mainly on solar energy and biomass.

About $70 \%$ of the populations of Bangladesh live in rural areas. The rural economy is characterized by slow growth, high unemployment, insufficient infrastructure and widespread poverty. Due to the lack of electricity

*Address correspondence to this author at the Department of Mechanical Engineering, Rajshahi University of Engineering \& Technology (RUET), Rajshahi-6204, Bangladesh; Tel/Fax: +880-721-750319;

E-mail: barun_ruet@yahoo.com
Table 1: Electricity Generation Scenario by Fuel Type [1]

\begin{tabular}{|c|c|c|}
\hline \multirow{2}{*}{ Fuel Type } & \multicolumn{2}{|c|}{ Generation Capacity } \\
\cline { 2 - 3 } & MWe & $\%$ \\
\hline \hline Natural gas & 5730 & 67.21 \\
\hline Furnace oil & 1904 & 22.34 \\
\hline Hydro & 220 & 2.58 \\
\hline Coal & 200 & 2.35 \\
\hline Diesel & 471 & 5.52 \\
\hline Total & 8525 & 100 \\
\hline
\end{tabular}

supply in rural areas, the rural population depends mainly on biomass as a source of energy. Over $70 \%$ of total primary energy consumption is covered by biomass, mainly agricultural waste and wood [2]. Only about $6 \%$ of the entire population has access to natural gas, primarily in urban areas. Biomass fuels, such as wood, cow dung and agricultural residues are collected mainly from the local environment and have become a traded commodity as cooking fuel. Most Bangladeshi households in rural areas (99\%) as well as urban areas $(66 \%)$ use biomass such as wood, cow dung, jute sticks or other agricultural wastes for cooking [2]. The electricity supply is not reliable though and peak demand cannot be met. In the rural areas only about $25 \%$ have electricity access [3]. Around $39.5 \%$ of total population of Bangladesh use kerosene as a fuel for lighting [2].

Power generation in Bangladesh largely depends on natural gas considering its apparent huge 
availability. The present share of renewable energy is only $0.5 \%$ [4]. However, in recent years, it was evident that actual scenario is different and adequate supply of natural gas has been at stake due to depleting existing gas reserves and non-exploration of new gas reserves. The uncertainty has been constraining development of further gas based power generation expansion program. Considering this situation, the government has diversified the fuel mix and under the new generation expansion plan substantial proportion is from liquid and coal based. In that case the above scenario will be drastically changed. Under the existing generation scenario renewable energy has a very small share to the total generation. However, under the changed perspective renewable energy would have a significant contribution given the global climate change scenario and carbon trading prospect. Bangladesh Power Development Board (BPDB), Rural Electrification Board (REB), Local Government Agency like Local Government Engineering Directorate (LGED) and a significant number of Private Sector agencies including NGOs are involved in renewable energy development. Noted Public Universities e.g Bangladesh University of Engineering \& Technology (BUET), Rajshahi University of Engineering \& Technology (RUET), Khulna University of Engineering \& Technology (KUET) and their affiliated Institutes are involved in research and development of Renewable Energy Applications.

The biggest renewable energy program in Bangladesh so far installed 900,000 units and ever increasing due to an integrated program undertaken by the government through its financial institution, IDCOL. IDCOL's program is considered as a successful model for installation of (solar home systems) SHSs in the world. Till now, national capacity of renewable energy based power is approx. $50 \mathrm{MW}$ [4].

Bangladesh has enormous potentiality in renewable energy development. The potential of development of solar photovoltaic (PV) has already been proven. Bangladesh has suitable geographical condition for solar power and receives an average daily solar radiation of $4-6.5 \mathrm{kWh} / \mathrm{m} 2$ [5]. Solar photovoltaic (PV) are gaining acceptance for providing electricity to households and small businesses in rural areas. Potential of Wind Energy is mainly in coastal areas and offshore islands. Micro hydro and mini hydro have limited potential in Bangladesh with exception of Chittagong Hill Tracts. Hydropower assessments have identified some possible sites from $10 \mathrm{~kW}$ to $5 \mathrm{MW}$ implementation of which is still at large.
Bangladesh has strong potential for biomass gasification based electricity. More common biomass resources available in the country are rice husk, crop residue, wood, jute stick, animal waste, municipal waste, sugarcane bagasse etc. This technology can be disseminated on a larger scale for electricity generation. Rice husks are among the most common agricultural residues in the world accounting for about one-fifth of unmilled rice dry wet. Rice husk gasifiers have been successfully operated in Indonesia, China, Thailand, Mali and India [6].

A large rice-husk power generation plant coming up at the north-western Thakurgaon district of Bangladesh will generate $400 \mathrm{KWh}$ of electricity mainly for small and medium sized rice mills. The project, first of its kind in the country, is in line with such power generation plants in the neighboring India and China. The private sector venture undertaken by Sustainable Energy \& Agro-resources Ltd (SEAL) will use the same technology employed in India, and will be fully operational in a year's time. Infrastructure Development Company Ltd (IDCOL), the market leader in private sector energy and infrastructure financing in Bangladesh is expected to fund the project. IDCOL plans to finance the venture for generating electricity, a total of $50 \mathrm{MW}$, through rice-husk gasification technology by 2012 [7]. At the moment, there is only one power plant in Bangladesh run by rice husk but it also requires diesel. Bangladesh's state-owned Infrastructure Development Company Ltd. (IDCOL) has sponsored a micro energy company called Dreams Power which, in collaboration with the World Bank and the Global Environmental Facility, inaugurated the country's first advanced, decentralized biomass power plant today. The facility, located in an unelectrified town named Kapashia (Gazipur district), is part of a rural electrification project that aims to reach about 700,000 citizens through renewables. The green power plant, the first ever its kind in Bangladesh, is a $250 \mathrm{~kW}$ biomass gasification facility that generates renewable electricity from abundant agricultural residues such as rice husks. It is estimated that Bangladesh produces around 10.12 million tones of rice husk per annum from about 50.63 million tones of paddy. About $4 \mathrm{mn}$ tons of rice husk are put to use for rice parboiling in majority of rice mills and domestic cooking, and it is also used as poultry and fish feed. The remaining portion and improvements in rice parboiling system are likely to increase the availability of rice husk for the present and future power plants.

However, the prospect of rice husk gasification is still undervalued and yet to be utilized according to its 
present worth and the information available on the literature about rice husk gasification in Bangladesh are very little. This paper addresses the existing energy scenario in Bangladesh and the possible alternatives using rice husk to meet the electricity demand, especially for off-grid solutions. The paper consolidates information from various studies on the availability of rice husk, its characterization and estimates possible power potential that can be realized. Environmental benefits as well as the scenario of using biomass gasification technology in the distributed generation mode from other developing countries are also highlighted. In the first phase of the study data collection has been accomplished from various sources and then analysis and recommendation has been done for power generation using biomass gasification.

\section{AVAILABILITY OF RICE HUSK IN BANGLADESH}

Bangladesh is an agricultural country and it's economy largely depends on agriculture. About $70 \%$ people earn their livelihood by agriculture and agrobased industry. Total area of Bangladesh is about $147570 \mathrm{~km}^{2}$, where the total agricultural land is about $90500 \mathrm{~km}^{2}$ which is $62.8 \%$ of the total area. Total arable land is $79700 \mathrm{~km}^{2}$ and is $55.3 \%$ of the total area. Aus, amon and boro are the main three types of rice are produced in Bangladesh. Total harvested land 12million hector and total rice production in 2011 was around 50.63 million tones [8]. The rice husk is the outer cover of the rice and on average it accounts for $20 \%$ of the paddy produced, on weight basis [9].

\section{CHARACTERISTICS OF RICE HUSK}

The husk surrounding the kernel of rice accounts for about $20 \%$, by weight of the harvested grain (paddy). In modern two-stage mills, the husk and the bran layer inside the husk are removed in separate stages; these mills generate about $200 \mathrm{~kg}$ of husk for each tonne of paddy [9]. In most of the very numerous small mills in developing countries, some or all of the bran is removed with the husk in a single-stage milling operation. The resulting husk mixture often represents $25 \%$ or more of the paddy. The energy content or caloric value of the husks varies somewhat with the rice variety, the amount of bran mixed with the husks, and the moisture content of the husks (usually 8 to $10 \%$ ). Most of the approximate fuel values cited in the literature on rice husks are close to $6,000 \mathrm{BTU} / \mathrm{lb}, 3000$ $\mathrm{kcal} / \mathrm{kg}$, or $15 \mathrm{MJ} / \mathrm{kg}$. The energy in $3 \mathrm{~kg}$ of husk approximately equals that in $1 \mathrm{~kg}$ of fuel oil or $1.5 \mathrm{~kg}$ of coal [10]. Somewhat higher fuel values have been indicated in tests of husks from small mills in developing countries; the inclusion of some bran with the husks tends to increase the percentage of carbon and dilute the ash in the mixture. Most rice husks contain between $15 \%$ and $20 \%$ ash, although even higher ash contents hive been recorded in some cases. The ash is $92 \%$ to $95 \%$ silica. The high ash contents and the characteristics of the ash impose several severe requirements on the design of the combustion or the gasification systems for the use of rice husk. Tables $\mathbf{2}$ and $\mathbf{3}$ show the important properties of rice husk. The higher heating value (HHV) indicates the energy content of a given biomass. The typical HHV of agricultural residue ranges between $15 \mathrm{MJ} / \mathrm{kg}$ and 17 $\mathrm{MJ} / \mathrm{kg}$.

Table 2: Proximate Analysis of Rice Husk [11]

\begin{tabular}{|c|c|}
\hline Component & \% of dry fuel \\
\hline \hline Fixed carbon & 16.22 \\
\hline Volatile Matter & 63.52 \\
\hline Ash & 20.26 \\
\hline Total & 100.00 \\
\hline
\end{tabular}

Table 3: Ultimate Analysis of Rice Husk [11]

\begin{tabular}{|c|c|}
\hline Component & \% of dry fuel \\
\hline \hline Carbon & 38.83 \\
\hline Hydrogen & 4.75 \\
\hline Oxygen(diff.) & 35.47 \\
\hline Nitrogen & 0.52 \\
\hline Sulphur & 0.05 \\
\hline Chlorine & 0.12 \\
\hline Ash & 20.26 \\
\hline Total & 100.00 \\
\hline HHV $(\mathrm{MJ} / \mathrm{kg})$ & $15-17$ \\
\hline
\end{tabular}

\section{GASIFICATION TECHNOLOGY}

During a gasification process, biomass is directly converted to synthesis gas (syngas) in a gasifier under a controlled amount of air. Syngas can be used in internal combustion (IC) engine to produce heat, or in a cogeneration system to produce heat and electricity. Previously, Kapur et al. [12]. calculated the unit cost of electricity of using rice husk gasifier based power generation system and evaluated its financial feasibility with utility supplier and diesel generated electricity. Abe 


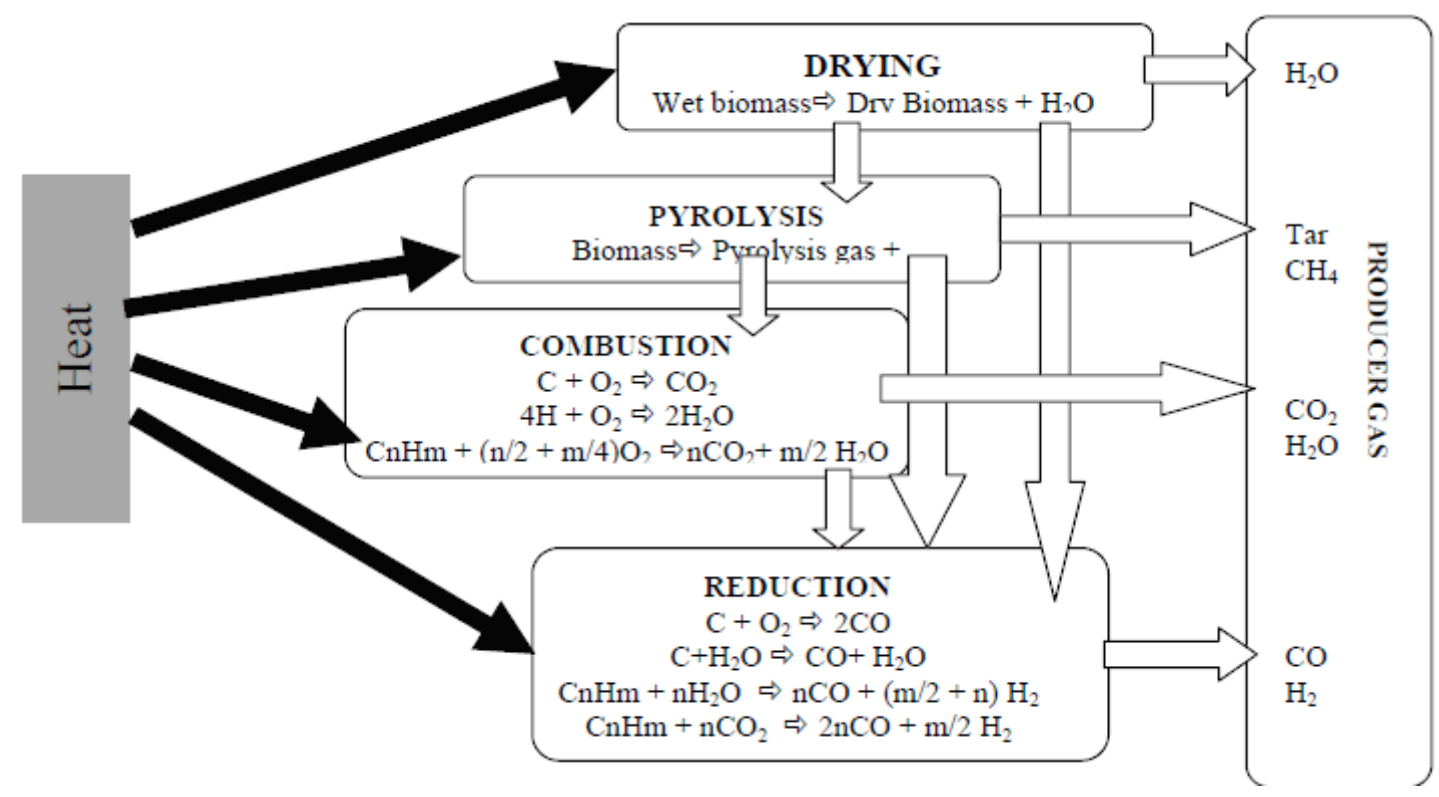

Figure 1: The reaction mechanism of biomass gasification process [16].

et al. [13] discussed the potential of rural electricity generation via biomass gasification system. The results suggest that even though agricultural residues such as rice husks may contain high energy potential, however, to supply a biomass gasification system in the long term may require tree farming in order to provide sufficient amount of resources [13]. These researches imply that the feasibility of these large scale projects is greatly dependent on the plant location that affects the resource availability and the incurred logistic costs of the selected biomass feedstock. On an industrial scale, biomass gasification and power generation systems have been well-established.

\subsection{Gasification Principle}

Biomass gasification is a multi step process. In practice, the gasification of the biomass particle occurs through a first particle drying step, followed by a pyrolytic step which leads to devolatilization and shrinking of the original particle. The last step being char gasification, the pyrolysis step occurs gradually from the surface to the centre of a biomass particle. The chemistry of biomass gasification is similar to that of coal gasification in the sense that thermal decomposition of both solids occurs to yield a mixture of essentially the same gases [14]. However, biomass gasification occurs under much less severe operating conditions than for coal feedstock because its main constituents, the high-oxygen cellulosics and hemicellulosics, have higher reactivity than the oxygendeficient, carbonaceous materials in coal [15]. The thermo-chemical processes involved in gasification are drying, pyrolysis, oxidation and reduction which shows in Figure 1.

The composition of producer gas is shown Table 4. The producer gas so obtained is a low calorific value gas with typical higher heating value in the range of 5.4-5.7 $\mathrm{MJ} / \mathrm{m}^{3}$ [17]. The producer gas can be directly burned in a burner to provide thermal energy or it can be used as a fuel in an engine to provide mechanical power or electricity. The actual biomass syngas composition depends on the gasification process, the gasifying agent, and the feedstock composition [18]. Various gasification technologies have been under investigation for converting biomass into a gaseous fuel. A characteristic of the various gasifiers is the way in which the fuel is brought into contact at the gasification stage.

Table 4: Composition of Producer Gas [19]

\begin{tabular}{|c|c|}
\hline Component & Composition (\%) \\
\hline \hline Carbon monoxide & $18-22$ \\
\hline Hydrogen & $13-19$ \\
\hline Methane & $1-5$ \\
\hline Carbon dioxide & $9-12$ \\
\hline Heavier hydrocarbons & $0.2-0.4$ \\
\hline Nitrogen & $45-55$ \\
\hline Water vapour & 4 \\
\hline
\end{tabular}

Four types of reactors exist: updraft or countercurrent gasifiers; downdraft or co-current 
gasifiers; cross-draft gasifiers and fluidized-bed gasifiers. In general, gasification technology is selected on the basis of available fuel quality, capacity range, and gas quality conditions as shown in Table 5 .

Table 5: Thermal Capacity of Different Gasifier Designs [18]

\begin{tabular}{|c|c|}
\hline Downdraft & $1 \mathrm{KW}-1 \mathrm{MW}$ \\
\hline Updraft & $1.1 \mathrm{MW}-12 \mathrm{MW}$ \\
\hline Fluidized-bed gasifier & $1 \mathrm{MW}-50 \mathrm{MW}$ \\
\hline Cross-draft gasifier & $10 \mathrm{MW}-200 \mathrm{MW}$ \\
\hline
\end{tabular}

Classification of biomass gasifiers based on the density factor (ratio of dense biomass phase to total reactor volume) is a simple and effective method of classification. The gasifiers can be classified into a) dense phase gasifiers b) lean phase gasifiers. In lean phase gasifiers e.g. fluidized bed, the biomass occupies very little reactor volume i.e. $0.05-0.2$. Most of the gasifiers employed for decentralized applications in developing countries are dense phase reactors, mostly fixed bed reactors, they have typical density factor of $0.3-.08$ [19]. There are two main types of fixed bed gasifiers are updraft and downdraft gasifier.

\subsubsection{Updraft Gasifiers}

In this type of reactor, air is taken in at the bottom, and the gas leaves at the top. The biomass moves counter to the gas flow and passes successively through drying, pyrolization, reduction, and hearth zones. Gases follow a natural upward movement as the increasing temperature reduces their density. Updraft gasifier can be designed to work under a natural or forced draft. With this configuration, the air or oxidizing agent entering gets in contact with the chars creating the combustion zone. The gases coming out of the combustion zone have to pass through the layer of chars above them created by the heat of the combustion zone. Here $\mathrm{CO}_{2}$ and $\mathrm{H}_{2} \mathrm{O}$ are reduced into $\mathrm{CO} \& \mathrm{H}_{2}$. The reduced gases still contain enough energy to pyrolyse the descending biomass along a range 200 to $500^{\circ} \mathrm{C}$, thus creating the chars that feed the combustion zone. In a reaction chain, pyrolysis gases also have sufficient temperature to dry the wet biomass entering above them. However, during pyrolysis, chemical, tars and oils are released and become part of the producer gases. This drawback restrains the application of the updraft gasifier, because these products released from pyrolysis would be detrimental in a heat engine; however, it could be used for heating applications [18]. Another major drawback in updraft gasifier is due to high temperature at the grate melting ashes \& leading to slagging.

\subsubsection{Downdraft or Co-Current Gasifiers}

In the downdraft gasifier, air enters at the middle level of the gasifier above the grate, and the resultant mixture of air and gas flows down into the gasifier reactor through the high temperature oxidation zone resulting in thermal cracking of volatiles resulting in a gas which has relatively lower tar content and is better suited for use in engines. This type of gasifier is cheap \& easy to make. Such systems have shorter contact times \& therefore are more responsive than up draught gasifiers to surge in gas demands that are experienced when fuelling engines [20, 21]. This gasifier is, however, preferred to updraft gasifier for internal combustion engines because of the low tar content with the syngas.

\subsubsection{Fluidized-Bed Gasification}

Fluidized-bed gasification was initially developed to overcome operational problems of fixed-bed gasification of fuels with high ash content, but is suitable for large capacities (more than $10 \mathrm{MW}$ ) in general [15]. The fuel is fed into a suspended (bubbling fluidized-bed) or circulating fluidized-bed hot sand bed. The bed behaves like a fluid and is characterized by high turbulence. Fuel particles mix quickly with the bed material, resulting in rapid pyrolysis and a relatively large amount of gases. Major problems with fluidized bed gasification are the resulting high tar content [17], incomplete carbon combustion, and poor response to load changes. Problems with feeding, instability of the reaction bed, and fly-ash sintering in the gas channels can occur with some bio-fuels [21]. There are two principal types of fluidized bed gasifiers namely, bubbling fluidized bed and circulating fluidized bed. Fluidized bed gasifiers have been the focus of appreciable research and development for large scale generation. Figure $\mathbf{2 a}, \mathbf{b}$ and $\mathbf{c}$ present the different types gasifier reactor [15].

\subsection{Comparison of Biomass Gasification Technologies}

The choice of one type of gasifier over other is dictated by fuel, its final available form, size, moisture content and ash content. Fixed bed gasifiers are more suitable for small scale power generation and industrial heating applications. Acceptable fuels for different gasifier types and their range is given in Table $\mathbf{6}$. 


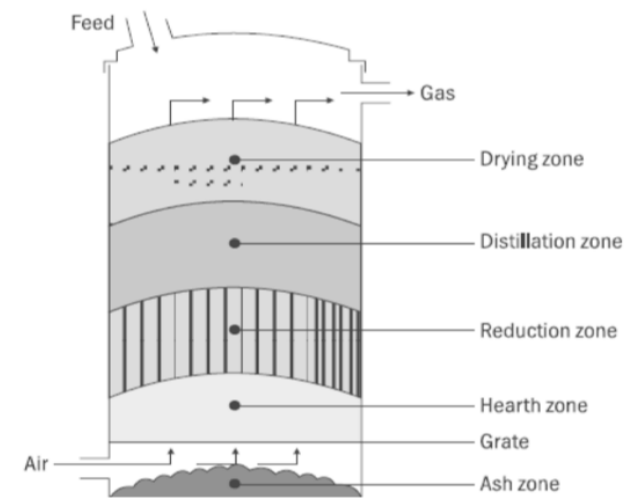

(a)

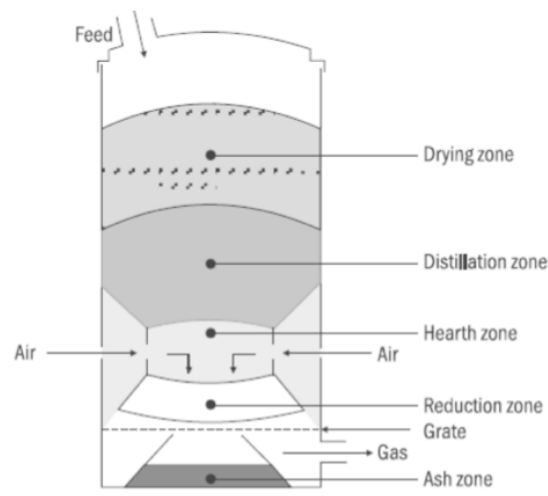

(b)

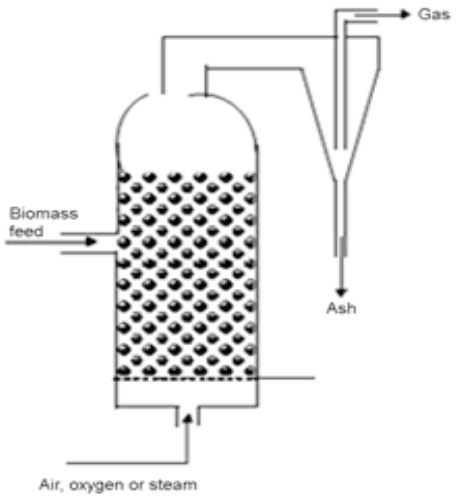

(c)

Figure 2: (a) Updraft gasifier. (b) Downdraft gasifier. (c) Fluidized bed gasifier.

Table 6: Gasifier Systems and Gasifier Fuels [22]

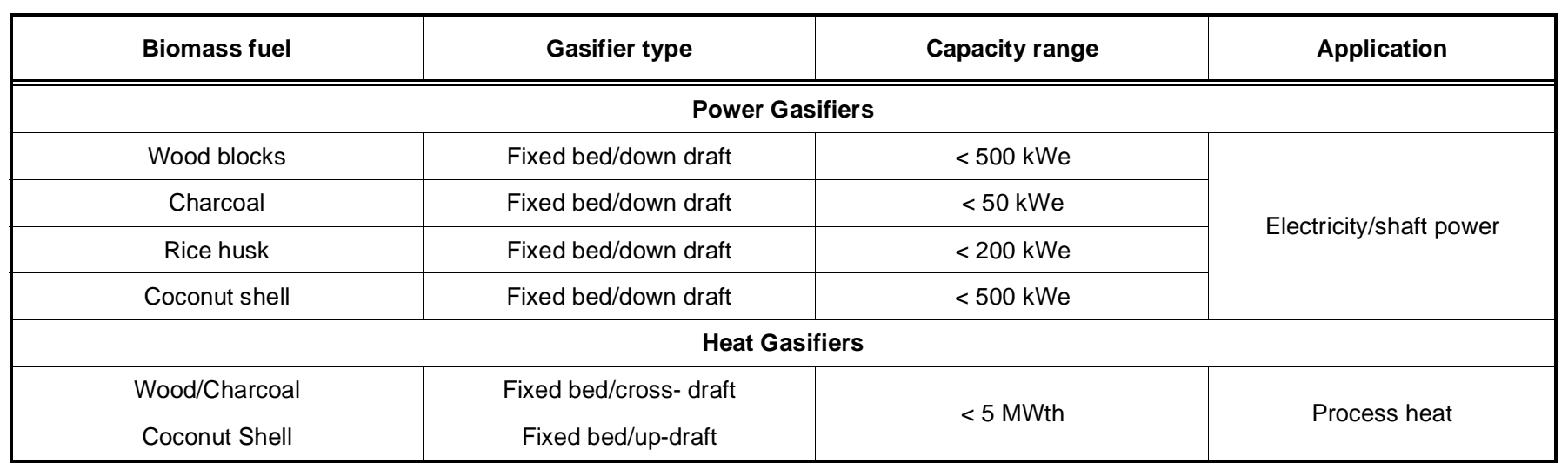

Downdraft gasifier is advantageous because of its flexible adaptation of gas production to load, low sensitivity to charcoal dust and tar content of fuel, better quality of gas, simple and low cost process and minimum maintenance required $[23,24,25]$. Downdraft gasifier system can be chosen for Bangladesh's perspective due to their simplicity in construction and low maintenance requirements. Also, the technologies of these systems are quite matured in the world.

\section{GLOBAL SCENARIO OF ELECTRICITY GENERATION FROM RICE HUSK GASIFICATION}

Rice husk is one of the finest fuels and it can be efficiently used as a sustainable energy resource. Use of rice husk for power generation has been studied and practiced widely. Rice husk based power plant has already proven to be economically feasible in China, Thailand, India and in Vietnam [22]. The huge production of rice in Bangladesh made it potentially more feasible place for using rice husk as energy source in biomass based power generation and co- generation. For generating electricity, the producer gas from the biomass gasifier is first cleaned and cooled and then used as a fuel in an IC engine. A generator coupled to the engine produces electricity. Biomass gasifier engine sets are typically available in capacities ranging from $10 \mathrm{kWe}$ to $500 \mathrm{kWe}$. Two types of engines are used. Diesel engines are modified and can be run on a mixture of diesel and producer gas. These are called dual-fuel engines. Typically $60-85 \%$ diesel is replaced with producer gas. Now $100 \%$ producer gas engines are also available -- as the name suggests these can operate on $100 \%$ producer gas.

Gasification for power generation technology started as early as the 1960s, characterized by a $60 \mathrm{~kW}$ rice hull gasification for power generation system. Now the $160 \mathrm{~kW}$ and $200 \mathrm{~kW}$ system are mainly adopted and there are dozens of these small rice husk gasifierpower generator sets in use. In 1998, the $1 \mathrm{MW}$ system with a circle fluidized bed (CFB) gasifer was developed by Guangzhou Institute of Energy Conversion, and constructed at a rice mill in the Fujian province of 
China. Based on the experiences from this first MWscale biomass gasification-power generation system, in 2000 a new demonstration plant with a capacity of $1.2 \mathrm{MW}$ was constructed at Sanya, Hainan Province of China [26, 27].

In recent years biomass gasifiers have been used for electrification of remote villages. The size of such systems can vary from $10 \mathrm{kWe}$ to $500 \mathrm{kWe}$. In India, several of the smaller size $(10-20 \mathrm{kWe})$ biomass gasifier systems have been established under two Government of India schemes called Remote Village Electrification (RVE) and Village Energy Security Programme (VESP) [29]. Apart from the Government programmes, several NGOs and corporate have also established such systems. There have been a few instances like $500 \mathrm{kWe}$ biomass gasifier based power plant at Gosaba island in Sundarbans (India) where large capacity gasifiers have been used. There are some examples of grid-connected biomass gasifier power plants. These are relatively large sized gasifier with capacities ranging in hundreds of $\mathrm{kW}$. In India a typical example is Arashi Hitech Bio power an independent power producer (IPP) has set up a gasifier based power plant linked to the State grid. It is located in Sultanpet village in Coimbatore district of Tamilnadu, where there is abundance availability of coconut shells. The power plant comprises a biomass processing system, gasification system, PLC based automation and control system, fully fledged water treatment plant, power package and a power evacuation system. In the first phase, an $800 \mathrm{~kg} / \mathrm{hr}$ gasifier system was integrated with a low speed marine diesel engine in July, 2002. The power plant has operated in the dual-fuel mode at an average load of $600 \mathrm{kWe}$ for nearly 6000 hours. The average liquid fossil replacement recorded is about $68 \%$, with specific biomass consumption being 0.6-0.7 $\mathrm{kg} / \mathrm{kWh}$. Recently the dual-fuel engine has been replaced with $5 \times 250 \mathrm{kWe}$ producer gas engines [28].

\section{ENVIRONMENTAL BENEFITS}

Gasification has potential to increase energy efficiency compared to combustion of biomass in a steam cycle. These carbon emission reductions may be tradable in carbon offset markets. Significant production of biochar reduces energy efficiency, if the char is not reburned. But biochar offers other environmental advantages that can more than make up for its energy efficiency penalty. Both fossil fuels and biomass release $\mathrm{CO}_{2}$ when they burn. The carbon released when burning fossil fuels originates from oil reserves, not from the atmosphere. Hence, fossil fuels are carbon positive in that they add new carbon dioxide to the atmosphere. In contrast, combustion of biomass, taken by it, is carbon neutral because the carbon released was first absorbed from the atmosphere by the biomass as it grew. In other words, the carbon cycle is closed. Combustion of biomass may still be carbon positive overall if fossil fuels are used in their production and transportation. Use of biomass has the potential of being carbon negative if, in using or producing it, carbon is stored in a form that is not released to the atmosphere. Biochar as a soil amendment significantly increases the efficiency of and reduces the need for traditional chemical fertilizers, while greatly enhancing crop yields [29, 30]. Production and transportation of chemical fertilizers is fossil fuel intensive and so reducing their use reduces associated carbon emissions. Moreover, char-amended soils have shown $50 \%$ to $80 \%$ reductions in nitrous oxide emissions, reduced runoff of phosphorus into surface waters, and reduced leaching of nitrogen into groundwater. The product gas will generally have low $\mathrm{NO}_{x}$ concentrations because gasification temperatures are not high enough to produce $\mathrm{NO}_{x}$ in significant quantities. However, when the product gas is burned in a boiler, turbine or engine, $\mathrm{NO}_{x}$ will be produced as it is in most combustion systems \& with all fuels. Nevertheless, it is easier to control the combustion of a gaseous fuel than the combustion of a solid fuel. Better control of combustion provides to reduce $\mathrm{NO}_{x}$ formation.

Some of the environmental benefits of the gasifier [19]:

- Gasification plants produce significantly lower quantities of criteria air pollutants.

- Gasification can reduce the environmental impact of waste disposal because it can use waste products as feedstock's generating valuable products from materials that would otherwise be disposed as wastes.

- Gasification plants use significantly less water and can be designed so they recycle their process water, discharging none into the surrounding environment.

- $\mathrm{CO}_{2}$ can be captured from an industrial gasification plant using commercially proven technologies.

- Gasification offers the cleanest, most efficient means of producing electricity from coal and the 
lowest cost option for capturing $\mathrm{CO}_{2}$ from power generation.

\section{POTENTIAL OF POWER GENERATION FROM RICE HUSK GASIFICATION}

Electricity generation from rice husk depends on the availability of raw materials and technology for conversion of rice husk to electricity. Gasification converts a traditional, low quality fuel to a modern day energy carrier i.e. combustible gas. Such conversion occurs at relatively high efficiencies and results in total convenience and process control. The process can be applied over a very wide range of output ratings (a few kilowatts to tens of megawatts) with only a small variation in overall efficiency and investment. Gasifiers with individual units being capable of supporting power generation at upto 500-800 kWe level; larger outputs need paralleling of more than one unit. Complete power generation systems including gasifiers, gensets, fuel handling sub-systems and grid paralleling subsystems, as needed and effluent treatment.

The process is equally applicable for electricity generation and a variety of thermal applications. Raw material availability is also a concern for larger plants. According to the rice mills owners association of Bangladesh, over 100,000 rice mills are scattered all over the country. But the mills are geographically concentrated in the four distinct cluster areas and $90 \%$ of them are small in capacity (5-10MT/day). Other than 4 distinct cluster areas for rice mills in Bangladesh, it will be difficult to keep the continuous supply to the plant [31].So, it's need to coupled with local availability of biomass, it provides for a truly distributed energy/power system at various output levels. The process is equally applicable for stand-alone utility and grid feeding. Almost all environmental pollution associated with biomass use can be eliminated. Various researcher shows that the downdraft gasifier is suitable for small scale rice husk gasification base power plant [21, 22]. For gasification based power plant consumption of rice husk is $1.86 \mathrm{~kg}$ per kWh electricity generation [32]. Considering half of the husk is used for rice parboiling and other domestic purposes and the surplus husk is to be used for power generation at continuous operation and estimated potential for power generation from rice husk around $310 \mathrm{MWe}$.

\section{CONCLUSION}

Rural areas in the developing countries are characterized by disperse population and a lack of infrastructure. Energy is the basic mean in improving the living standard and productivity. Power generation in Bangladesh is still mono-fuel dependent, i.e indigenous natural gas. The rest is from furnace oil, coal and hydropower. Share of renewable is still insufficient. Bangladesh has a good potential form power generation from rice husk gasification and has estimated around $310 \mathrm{MWe}$. There are seasonal, geographical distribution and other variations in the availability of this potential. Establishment of rice husk based power plants in rural areas will be led to an enormous change in the lifestyle of the local communities. Increased lighting would also be indirectly helped the community by increasing the business hours in the market area, reducing thefts, improving health conditions and encouraging new business developments like computer shops and photo studios. Gasification could reduce significantly reduce the GHG emission. Each Megawatt of power generated from rice husk plant has resulted in reduction of carbon dioxide $\left(\mathrm{CO}_{2}\right)$ emissions by about 5800 tonnes every year. Global production of biomass and biofuel is growing rapidly due to the increasing price of fossil fuels, growing environmental concerns, and considerations regarding the security and diversification of energy supply. There are many scenarios that predict a high potential for biomass in the future. Rice husk gasification can offer an attractive alternative renewable energy system especially in cluster areas where large rice mills are available. Power plant should be installed beside the rice mills to make it feasible.

Following actions plan is recommended for enhancing the effective utilization of rice husk as an energy source:

$>$ Government of Bangladesh would need to amend energy policy so that the gasification plants can run to their full capacity and can sell the surplus electricity to the grid.

$>$ Encouragement of local and foreign entrepreneurs, NGOs and other communitybased organizations to act as energy service companies. These companies will be responsible for operation and maintenance of gasifier. Direct purchase of fuel biomass from individual villagers will provide them livelihood earning opportunity.

$>$ Provision of government subsidies for the installation of such gasification power plants. Government can seek funds from different foreign aids. Also carbon trade can be an option. 
Regular information and awareness programs should be conducted to convince the rural population about the potential of gasifier-based generation. This will increase the number of local consumers, and hence, the cash flow central regulation of the tariff structure is also required through an appropriate policy.

\section{REFERENCES}

[1] BPDB- Bangladesh Power Development Board, "Key Statistics", December, 2012, http://www.bpdb.gov.bd/bpdb/ index.php?option=com_content\&view=article\&id=5\&ltemid=, Accessed on 25 April, 2013.

[2] Population and housing census, 2011,http://www.bbs.gov.bd/ WebTestApplication/userfiles/Image/BBS/Socio_Economic. pdf

[3] Energy, Power and Environment news of Bangladesh, http://www.energybangla.com/. Accessed on 27 May, 2013

[4] Renewable energy Bangladesh. Power division, Ministry of Power, Energy and Mineral Resources, Government of the People's Republic of Bangladesh, http://www.powerdivision. gov.bd/user/brec/49/89, Accessed on 22 April, 2013.

[5] Islam MR, Islam MR, Beg MRA. Renewable energy resources and technologies Practice in Bangladesh. Renewable Sustainable Energy Rev 2008; 12(2): 299-43. http://dx.doi.org/10.1016/j.rser.2006.07.003

[6] Bhattacharya SC, Salam PA. A review of selected biomass energy technologies, Asian Regional Research Programme in Energy, Environment and Climate (ARRPEEC). Asian Institute of Technology (AIT), Thailand 2006.

[7] Infrastructure Development Company Ltd. http://www.idcol. org/energyProject.php. Accessed on 15 May, 2013.

[8] FAO FAOSTAT Statistics Database, 2011. Available at http://www.faostat.fao.org. Accessed on 21 May, 2013.

[9] Baqui MA. Present status and future potential of utilization of rice-by-products in Bangladesh. In Proceedings of the joint international conference on agricultural engineering and technology. Bangl Soc Agric Eng 1997; 1: 284-88.

[10] Schaffer \& Associates International. Rice Husk to Energy: A Preliminary Assessment for the Republic of Mali USA 2005.

[11] Jenkins BM, Baxter LL, Miles TR. Combustion properties of biomass. Fuel Proces Technol 1998; 54: 17-46. http://dx.doi.org/10.1016/S0378-3820(97)00059-3

[12] Kapur T, Kandpal TC, Garg HP. Electricity generation from rice husk in Indian rice mills: potential and financial viability. Biomass Bioenergy 1996; 10: 393-403.

http://dx.doi.org/10.1016/0961-9534(95)00116-6

[13] Abe H, Katayama A, Sah BP, Toriu T, Samy S, Pheach P, et al. Potential for rural electrification based on biomass gasification in Cambodia. Biomass Bioenergy 2007; 31: 65664. http://dx.doi.org/10.1016/j.biombioe.2007.06.023

[14] Milne TA, Abatzoglou N, Evans RJ. Biomass gasifier; Tars: Their nature, Formation and Conversion. NREL Technical Report 1998.

[15] Quaak P, Knoef H. Energy from Biomass-A Review of Combustion and Gasification Technologies. WB Technical Paper No 422-Energy Series 1999.
[16] Panwar NL. Design and performance evaluation of energy efficient biomass gasifier based cook stove on multi fuels. Springer Science + Business Media 2009.

[17] Kishore VVN, Ed. Renewable Energy Engineering and Technology a knowledge compendium. New Delhi: The Energy and Resources Institute 2008.

[18] Dayton D. A Review of the Literature on Catalytic Biomass Tar Destruction, Milestone Completion Report 2002, NREL, Golden, Colorado, USA, NREL/TP.

[19] T E R I. RETs II theme - Thermal applications of biomass gasifier in SMiEs New Delhi: The Energy and Resources Institute 2006; p. 55. [Project Report No. 2005BE28].

[20] Turare C. Biomass Gasification Technology and Utilization. Artes Institute, University of Flensburg, Germany 1997.

[21] Maniatis K. Progress in Biomass Gasification: An Overview. Progress in Thermochemical Biomass Conversion, ed. A. Bridgwater, Blackwell Publishing Ltd. Oxford, UK 2001.

[22] Bhattacharya SC, Salam PA. A review of selected biomass energy technologies, Asian Regional Research Programme in Energy, Environment and Climate (ARRPEEC). Asian Institute of Technology (AIT), Thailand 2006.

[23] Bridgwater AV, Evans GD. An Assessment of Thermo chemical Conversion Systems for Processing Biomass and Refuse, Energy Technology Support Un (ETSU) on behalf of the Department of Trade, ETSU B/T1/00207/REP 1993.

[24] Paisley MA, Farris MC, Black J, Irving JM, Overend RP Commercial Demonstration of the Battelle/FERCO Biomass Gasification Process: Startup and Initial Operating Experience. Presented at the 4th Biomass Conference of the, Americas, Volume 2.

[25] Environmental Protection Agency Combined Heat and Power Partnership (EPA-CHP), Biomass conversion technologies in biomass combined heat and power catalog of technologies, Environmental Protection Agency, United States 2007.

[26] Wu CZ, Huang H, Zheng SP, Yin XL. An economic analysis of biomass gasification and power generation in China. Bioresour Technol 2002; 83: 65-70. http://dx.doi.org/10.1016/S0960-8524(01)00116-X

[27] Lu PM, Xiong ZH, Chang J, Wu CZ, Chen Y, Zhu JX. An experimental study on biomass air-steam gasification in fluidized bed. Bioresour Technol 2004; 95: 95-101. http://dx.doi.org/10.1016/i.biortech.2004.02.003

[28] Gokhale AM, Gupta AK, Kishwan J, Bahuguna VK, Sanjappa $\mathrm{M}$, Maithel $\mathrm{S}$, et al. National Mission on Decentralized Biomass Energy for Villages and Industries 2006; p. 62.

[29] Laird D, Fleming P, Wang BQ, Horton R, Karlen D. Biochar impact on nutrient leaching from a Midwestern agricultural soil. Geoderma 2010; 158: 436-42. DOI: 10.1016/j.geoderma.2010.05.012.

[30] Husk B, Major J. Commercial scale agricultural biochar field trial in Québec, Canada, over two years: Effects of biochar on soil fertility, biology, crop productivity and quality. Disponible en ligne 2010: http://www.blue-leaf.ca/mainen/files/BlueLeaf\%20Biochar\%20Field\%20Trial\%200809\%20Report-2\%20EN.pdf

[31] Ahiduzzaman M. Rice Husk Energy Technologies in Bangladesh. Agricultural Engineering International: the CIGR Ejournal 2007; Invited Overview No. 1. Vol. IX.

[32] Singh RI. Combustion of Biomass in an Atmospheric Fbc: An Experience and Study. Paper presented at the International Conference in Advances on Energy Research Indian Institute of Technology Bombay 2007; 12-15. 